\title{
Research on the Construction of Practical Teaching System of Application Oriented Undergraduate Logistics Management Specialty \\ -- Taking Wenzhou Business College as an Example
}

\author{
Xiaozhen Dai ${ }^{1, a}$, Pingyu Yang ${ }^{1, b}$, Pingguo Chen ${ }^{1, c}$, Zhenkai Lou ${ }^{1, d}$ \\ ${ }^{1}$ Wenzhou Business College, Wenzhou, Zhejiang 325000 \\ ${ }^{a}$ email, ${ }^{\text {bemail, }}{ }^{\mathrm{c} e m a i l,}{ }^{\mathrm{d}}$ email,
}

Keywords: Application Oriented Undergraduate; Logistics Management; Practice Teaching System

\begin{abstract}
The construction of practical teaching system is the key to the success of the practice teaching. Taking Wenzhou Business College as an example, the basic framework of practical teaching system of application oriented undergraduate logistics management specialty is analyzed. This paper expounds how to construct the practical teaching system of logistics management specialty from four aspects, the design of practical teaching link, the construction of practical environment, the construction of practical team and the guarantee of practical management.
\end{abstract}

\section{Introduction}

Modern logistics industry is a composite service industry which integrates transportation, warehousing, freight forwarding, information and other industries, and is the basic and strategic industry to support the development of national economy. Practical teaching is an important part of higher education, and it is also an important link of College Students' theory and practice, as well as an important way to cultivate students' practical ability. Practice teaching system to reflect the teaching practice in the talent cultivation process and theoretical teaching with each other, relying on each other, is to train the students' practice ability and innovation ability, improve the comprehensive quality of students an important basis for the implementation. How to reasonably construct the practical teaching system, so that students can improve their practical ability in practical teaching, so that students can cultivate their professional quality in practical work, and combine theory with practice. Enhance the comprehensive ability of students, to achieve the ability of graduates and business needs of the seamless connection, the realization of the employment has become an urgent need to solve the problem. This article takes the Wenzhou business college logistics management major as an example, expounds the logistics management specialty practice teaching system construction.

\section{The Goal and Principle of Practical Teaching System}

(1) the principle of objective. Construction of practical teaching system must be closely around the logistics management professional personnel training goal as the center, according to the demands of logistics management personnel, design corresponding link of practice teaching, the students practice ability and job requirements consistent; (2) the principle of systematization. Follow the laws of cognition and education. By using the method of system science, in accordance with the composition of the status of practical teaching activities of each link and between the intrinsic link, forming system of practice teaching system, and runs through the whole process of teaching; (3) the overall optimization principle. To achieve the coordination and unity of the elements of practice teaching activities, pay attention to the mutual cooperation, mutual support and mutual penetration 
of each teaching link; (4) the principle of standardized management. In practice teaching system to regulate the practice of teaching management, to develop a scientific and reasonable comprehensive assessment standards and requirements; (5) theory with practical principles. Practice teaching system in the longitudinal direction and theory teaching complement each other, horizontal and theoretical teaching is relatively independent but also cooperate with each other, the formation of the theory teaching and practice teaching system.

\section{The Basic Framework of the Practical Teaching System}

Practical teaching system is an organic whole, which is composed of various elements of practical teaching activities, and it is the main way to cultivate students' practical ability. Practice teaching system consists of four parts: practice teaching link, practice teaching environment, practice teaching team and practice teaching management. Wenzhou business college logistics management professional practice teaching system structure as shown in figure 1.



management professional practice teaching system structure diagram

\section{The Construction of Practical Teaching System of Logistics Management Specialty}

Practice Teaching Link Design. Practice teaching link to carry on the logistics basic skill and practical problem solving ability training. Practice teaching should break through the order of "first theory and post practice", which can be in parallel with the teaching of theory and practice. On the basis of research about colleges and universities of professional practice teaching link design and its 
advantages. The practice link is divided into basic skills module, professional skills module and comprehensive skills module, by course experiment, course training, Off-campus practice training, subject contest and professional sports meeting to complete. The relationship between practical teaching, curriculum and practical ability is shown in Table 1.

Table 1 Relationship of practical teaching, curriculum and practice ability

\begin{tabular}{|c|c|c|c|}
\hline Practice & Belon & Course name & Training practical ability \\
\hline teaching link & $\mathrm{g}$ module & & \\
\hline $\begin{array}{l}\text { social } \\
\text { practice }\end{array}$ & \multirow{5}{*}{$\begin{array}{l}\text { Basic } \\
\text { skills } \\
\text { module }\end{array}$} & social practice & \multirow{5}{*}{$\begin{array}{l}\text { Improve students' basic } \\
\text { knowledge ability, moral character, } \\
\text { team spirit, humanistic quality. }\end{array}$} \\
\hline $\begin{array}{l}\text { Two } \\
\text { Courses } \\
\text { practice }\end{array}$ & & $\begin{array}{c}\text { Two Courses } \\
\text { practice }\end{array}$ & \\
\hline $\begin{array}{c}\text { Quality } \\
\text { development }\end{array}$ & & $\begin{array}{c}\text { Quality } \\
\text { development }\end{array}$ & \\
\hline $\begin{array}{l}\text { Computer } \\
\text { application }\end{array}$ & & $\begin{array}{l}\text { University } \\
\text { Computer }\end{array}$ & \\
\hline $\begin{array}{c}\text { Foreign } \\
\text { language } \\
\text { listening and } \\
\text { speaking }\end{array}$ & & College English & \\
\hline \multirow{5}{*}{$\begin{array}{c}\text { Course } \\
\text { experiment }\end{array}$} & \multirow{7}{*}{$\begin{array}{l}\text { Profession } \\
\text { skills } \\
\text { module }\end{array}$} & Statistics & Using Excel software to process data \\
\hline & & Operations research & $\begin{array}{c}\text { Practical problem modeling, } \\
\text { professional software process model }\end{array}$ \\
\hline & & $\begin{array}{l}\text { Statistical analysis } \\
\text { of management }\end{array}$ & $\begin{array}{l}\text { Using SPSS to process and analyze } \\
\text { logistics data }\end{array}$ \\
\hline & & $\begin{array}{c}\text { Management } \\
\text { communication }\end{array}$ & Communication skills, team work \\
\hline & & $\begin{array}{l}\text { ERP principle and } \\
\text { application }\end{array}$ & $\begin{array}{l}\text { Understand the operation of the } \\
\text { enterprise, to master the operation of } \\
\text { ERP system }\end{array}$ \\
\hline \multirow{2}{*}{$\begin{array}{l}\text { Course } \\
\text { training }\end{array}$} & & $\begin{array}{l}\text { Customer service } \\
\text { training }\end{array}$ & $\begin{array}{l}\text { Communication, compression, customer } \\
\text { service system operation }\end{array}$ \\
\hline & & $\begin{array}{l}\text { Sand table } \\
\text { simulation training }\end{array}$ & Enterprise operation decision \\
\hline $\begin{array}{l}\text { Off-campus } \\
\text { practice } \\
\text { training }\end{array}$ & $\begin{array}{l}\text { Comprehe } \\
\text { nsive skills } \\
\text { module }\end{array}$ & $\begin{array}{c}\text { Logistics } \\
\text { management } \\
\text { position function } \\
\text { training }\end{array}$ & $\begin{array}{c}\text { Knowledge of logistics related position } \\
\text { ability requirement }\end{array}$ \\
\hline
\end{tabular}




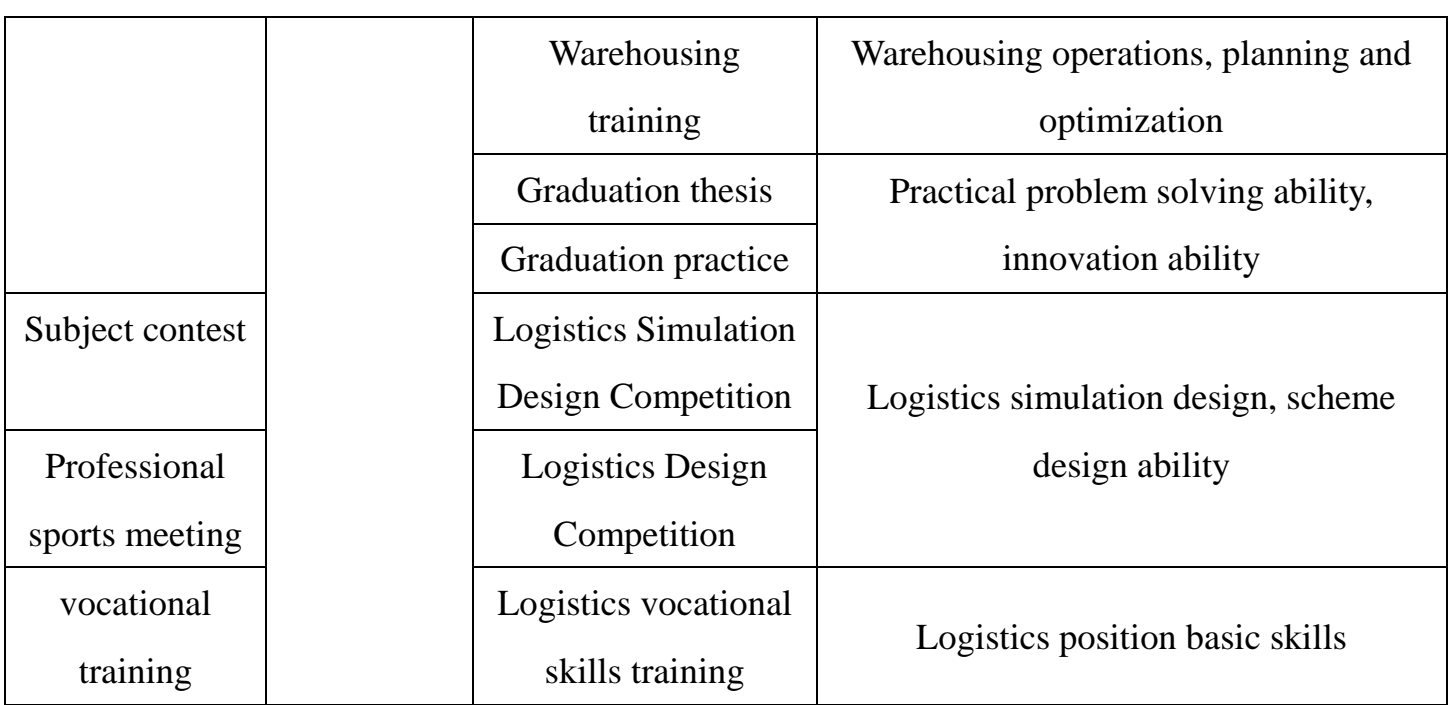

Practice Teaching Environment Construction. In order to meet the requirements of practical teaching, the environment of the laboratory, the practice base, the subject contest and the professional sports meeting of the college is set up. The laboratory mainly completes the practice link and the simulation class practice link in the class. Therefore, college established "logistics system simulation laboratory" to complete the simulation practice link, establish a "comprehensive logistics training room", management communication training room "," ERP training room "laboratory to complete the link of practice in class.

Outside-school practical bases mainly complete the operation and comprehensive practice link, by way of post operation, the "daily customer service platform", "summer storage practice platform" and "double eleven logistics experience platform". Daily customer service platform for students to accept the company's one-week professional customer service training, the use of existing customer service system, take over the logistics customer service is the most difficult problem. From the running situation, the average value of the quality of customer service work to achieve excellence, training the ability of students to communicate and deal with unexpected problems, and run three years, a total of more than 50 thousand single work completed. Some students in the internship period with the enterprise to reach the employment agreement, the realization of graduation is employment; "summer storage practice platform", a month summer practice in warehouse, live and eat in the warehouse, students can understand the mode of storage base operation, master a complete set of warehousing operations and training students in warehousing operation ability, new facilities and equipment, and the logistics information system's ability to use. "Double eleven logistics experience platform", the students one week after the double eleven, in enterprise workload of the largest transit, warehousing base and Ministry of sorting, packaging, assembly and distribution operation practice and students can realize the logistics busiest working scene, the ability to exercise high load work, contact with different levels of staff, communicate and coordinate ability. From three off-campus training platform running situation, in recent years, the logistics management professional graduates had left $30 \%$ in the internship unit employment, and job hopping rate is very low. It shows that the depth of cooperation between schools and enterprises, which is based on the project platform, can effectively improve the practical ability of logistics personnel, and reduce a large number costs of recruitment for enterprises.

Practice Teaching Team Construction. (1) Bring in talents without restraint of style, expand the source of practice teaching team. Change the emphasis on higher education, light practice teaching ability team building philosophy, practice teaching team introduction to practical ability of teachers as the main evaluation standards, increase the introduction of high professional quality and 
rich practical experience of management personnel, professional and technical personnel from the business and technology related industries sector.

(2) Go out and bring in, enrich the teaching staff. Scientific formulation of teacher enterprise training and learning system, and provisions of all logistics teachers must serve temporary positions in logistics enterprises or industry associations half a year, the units shall be for the school enterprise cooperation unit, the strict implementation of enterprise time and attendance system, during the attachment monthly report sending progress. It greatly enhances the practical teaching ability of logistics management professional teachers, a lot of teachers complete the transformation of the double-qualified teachers. At the same time, invite the enterprises and relevant industry technical department high professional quality actively, experienced management personnel and professional and technical personnel as a part-time teacher, complete the practice related links in the professional courses and practice courses teaching. Encouraged by the college, most of the part-time teachers choose the form of the field practice teaching, and the teaching effect is better.

(3) Training and improving the practical teaching ability. College focus on the sustainable development of the teachers' professional, in addition to serving temporary positions to enhance practice teaching ability, we encouraged logistics management professional teachers to actively participate in the training, obtain Logistics professional certification, improve the double-qualified teachers ratio; Encourage professional teachers to take a regular, irregular exchange of the way, to invite the practical ability to participate in practice teaching and discussion, and constantly improve the ability of practice teaching; guiding the logistics professional teachers to carry out technical services for enterprises, and constantly accumulate the actual work experience, improve the practical teaching ability.

Practice Teaching Management Support. (1) Establish Professional construction Steering Committee. Form the Steering Committee composed of experts in the industry, government departments, industry associations, corporate executives, regular of logistics management professional development and training plan, and practice teaching are discussed, actively explore the practice teaching new mode, practice teaching new ideas. In promoting the application oriented undergraduate construction, logistics management professional practice teaching hours accounted for $36 \%, 31 \%$ of the credits, two indicators are beyond the application oriented undergraduate logistics management professional requirements.

(2) various fund sources. The fund sources of practice teaching of logistics management was major form college daily funds invested and school enterprise cooperation unit. College will be the construction of laboratory training base construction, experimental teaching and research and experimental teaching research and reform funds included in the college routine budget. Enterprises of cooperation unit investment funds, such as customer service platform was the cooperation between college and Wenzhou S.F. Express Co., Ltd. in practical projects, practice platform in campus, platform of hardware and software were by the enterprises investment, including computers, high fidelity headphone and customer service software system, invested more than 20 million yuan. Also in our college logistics management professional school enterprise cooperation practice link were paid internship, such as customer service platform three years' cumulative distribution of student internship subsidy nearly 20 million yuan, greatly mobilized the enthusiasm of students, enhance the practice effect.

(3) Construction of practical teaching management platform. In order to meet the needs of practice teaching management, we have established the Moodle practice platform, graduation thesis platform and laboratory operation platform. Moodle internship platform with all the functions of the E-Learning platform, provides discussion areas, learning logs, chat rooms, learning resources, unit 
summary and online surveys, more than a dozen kinds of curriculum activities. At present, all the practice of logistics management was carried out on the Moodle platform. Graduation thesis platform can complete all work the contents of graduation thesis, from released graduation thesis topic to inputted scores, all the guidance process records on the platform, the realization of the combination of the process evaluations and examination results. Laboratory operation platform is a process management platform for laboratory application, experimental content arrangement and laboratory use.

(4) Improve the practice management rules and regulations. In the course of practice teaching management, we always adhere to the principle of "practice teaching management not only serve the practice teaching but also command the practice teaching", and had promulgated a series of rules and regulations of teaching management. Such as "the undergraduate graduation design (Thesis) diversification management approach ", the third party adopted research report, business planning, winning first prize in subject contest more than the province level, national student innovation project, $2 \mathrm{~b}$ above paper, publishing book and national patent could be instead of the graduation design (paper). "Open laboratory management approach", from the principles, conditions and forms, organization implementation, incentive mechanism, and other aspects of the implementation of laboratory opening policy. "student summer professional practice implementation method", "the laboratory construction work procedure" and so on.

(5) Diversified practice credit management. In order to meet the individual needs of students' practice, take advantage of the existing logistics practice platforms, give full play to students' initiative, we took diversified practice credit management. Such as the daily customer service platform reached 500 workloads every day, students could apply for a practical credit. Working in school enterprise cooperation unit headquarters and warehousing base every 200 hours could apply for a practice credits. Greatly mobilized the enthusiasm of students in practice, some students had completed all the practical credits except graduation thesis when they were junior.

\section{Conclusion}

The construction of practical teaching system of logistics management specialty is a complicated system engineering. This paper use Wenzhou business college for example, from the practical teaching system of logistics management four aspects of practice link design, practice environment building, practice teaching team construction and practice teaching management, to explain how to construct the practical teaching system of logistics management professional. Colleges and universities should according to their respective professional orientation and professional training objectives, give full play to the resources of their own, reasonable design practice teaching link, efforts to build practical teaching practice environment, and strive to build good practice teaching team, efforts construction guarantee the practice teaching practice management mechanism, to explore Logistics Management Specialty practice teaching system with its own characteristics.

\section{Reference:}

[1] Huanhuan Zhang. Literature review on the research of practical teaching system[J]. Data of Culture and Education 2013 (01), pp:143-146

[2] Liangzhong Shen, Ying Li, Xiaojie Wan, Wei Chen. Research on practice management mode based on Moodle[J]. China Electric Power Education.2014(04), pp:145-146

[3] Jinlian Shi. Problems and Countermeasures of practical teaching management in Colleges and universities [J]. Education and Vocation, 2010 (08), pp:154-156 
[4] Xiaozhen Dai,Pingyu Yang, Wei Lin. Research on the construction of Applied Undergraduate Specialty in Local Colleges -- Taking City College of Wenzhou University Logistics Management Major as an example [J]. The Guide of Science \& Education, 2016 (05), pp:17-18

[5] Kaiqin Li. Exploration and Practice on the construction of the team of double-qualified teachers[J]. China University teaching, 2010 (12), pp:73-75

[6] June Zhang. An analysis of practical teaching system of application oriented university management specialty--Taking logistics management major as an example [J]. Heilongjiang Researches on Higher Education ,2013(02),pp:166-169 